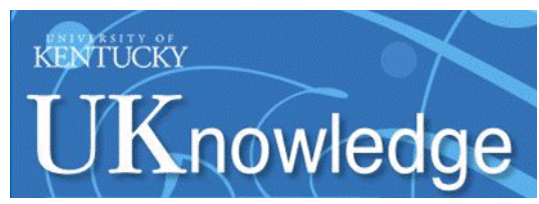

University of Kentucky

UKnowledge

\title{
Rotational and Continuous Grazing of Sheep in the Inner Mongolian Steppe of China
}

\author{
C. J. Wang
}

Christian-Albrechts-University Kiel, Germany

B. M. Tas

Christian-Albrechts-University Kiel, Germany

T. Glindemann

Christian-Albrechts-University Kiel, Germany

K. Mueller

Christian-Albrechts-University Kiel, Germany

Anna Schiborra

Christian-Albrechts-University Kiel, Germany

See next page for additional authors

Follow this and additional works at: https://uknowledge.uky.edu/igc

Part of the Plant Sciences Commons, and the Soil Science Commons

This document is available at https://uknowledge.uky.edu/igc/21/9-3/19

The XXI International Grassland Congress / VIII International Rangeland Congress took place in Hohhot, China from June 29 through July 5, 2008.

Proceedings edited by Organizing Committee of 2008 IGC/IRC Conference

Published by Guangdong People's Publishing House

This Event is brought to you for free and open access by the Plant and Soil Sciences at UKnowledge. It has been accepted for inclusion in International Grassland Congress Proceedings by an authorized administrator of UKnowledge. For more information, please contact UKnowledge@lsv.uky.edu. 


\section{Presenter Information}

C. J. Wang, B. M. Tas, T. Glindemann, K. Mueller, Anna Schiborra, P. Schoenbach, M. Gierus, Friedhelm Taube, and A. Susenbeth 


\section{Rotational and continuous grazing of sheep in the Inner Mongolian steppe of China}

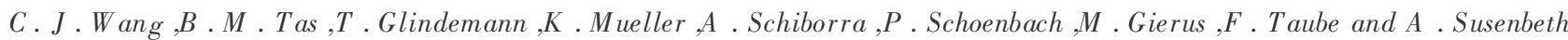
Institute of Animal Nutrition and Physiology,Christian-A lbrechts-University Kiel ,Hermann-Rodewald-Str . 9 ,24118 Kiel , Germany,E-mail address :susenbeth@aninut.uni-kiel.de

Key words : rotational and continuous grazing ,feed intake, digestibility ,live weight gain

Introduction The Inner Mongolia steppe of China is traditionally used for grazing. In the last three decades overgrazing by sheep led to a sparse cover of vegetation in winter that enables soil erosion and hence degradation of the grassland,which may be influenced by grazing system. The objective of this study-which is part of the Sino-German DFG research cooperation M AGIMwas to investigate the effects of rotational and continuous grazing on chemical composition of herbage ,herbage mass (HM) ,feed intake and digestibility ,and live weight gain (LWG) of sheep grazing at a moderate stocking rate of 4.5 sheep/ha on the Inner Mongolian steppe of China .

Materials and methods In the growing season from mid June until mid September in 2005 and 2006 a grazing experiment was conducted comparing a continuous and rotational grazing system with one replication. In the continuous system the sheep remained on one 2 ha plot throughout the season,whereas in the rotational system the plot was subdivided into four paddocks of 0.5 ha each and sheep were moved to the next paddock every 10 days. The stocking rate was 4.5 yearling sheep per ha. The chemical composition of herbage was determined with NIRS and HM was measured using exclosure cages. The intake of organic matter (OMI) was calculated by daily output of fecal OM ,estimated by the external marker titanium dioxide ,and by OM digestibility ( $\mathrm{OOM}$ ) of herbage ingested by sheep. The dOM w as estimated by the fecal crude protein (CP) method (Wang 2007). Intake of digestible OM (dOMI) was calculated by OMI multiplying with dOM ,and intake of metabolisable energy ( MEI ,MJ/d) by multiplying dOMI ( kg/d) with 16 ( MJ/kg) ,as described by McDonald et al . (1988) .

Results The concentration of CP was lower and NDF higher witht rotational than with continuous grazing . The OMI ,dOM and MEI with rotational grazing were lower with $1.09 \mathrm{~kg} / \mathrm{d}, 54.9 \%$ and $9.6 \mathrm{MJ} / \mathrm{d}$, respectively ,than with continuous grazing with $1.31 \mathrm{~kg} / \mathrm{d}, 57.4 \%$ and $12.0 \mathrm{MJ} / \mathrm{d}$, respectively. How ever ,the grazing systems did not affect HM and LWG of sheep. The annual precipitation was low with $166 \mathrm{~mm}$ in 2005 and $304 \mathrm{~mm}$ in 2006 compared with the average value of the last 30 years of $350 \mathrm{~mm}$,which influenced the measured variables in different years .

Table 1 The measured variables in rotational and continuous grazing system in 2005 and 2006

\begin{tabular}{|c|c|c|c|c|c|c|c|}
\hline \multirow{2}{*}{ Item } & \multicolumn{2}{|c|}{ Rotational grazing } & \multicolumn{2}{|c|}{ Continuous grazing } & \multirow{2}{*}{ SEM } & \multicolumn{2}{|c|}{$P$ value } \\
\hline & 2005 & 2006 & 2005 & 2006 & & GS & Year \\
\hline OM \% & 94.3 & 93.1 & 94.9 & 92.7 & 0.12 & 0.78 & $<0.001$ \\
\hline СР \% & 8.1 & 11.9 & 8.8 & 13.0 & 0.21 & 0.001 & $<0.001$ \\
\hline NDF \% & 73.3 & 69.1 & 72.0 & 67.8 & 0.24 & 0.016 & $<0.001$ \\
\hline HM ,kg/ha & 592 & 490 & 546 & 314 & 35.9 & 0.14 & 0.03 \\
\hline OM I ,kg/d/sheep & 1.03 & 1.14 & 121 & 1.27 & 0.02 & $<0.001$ & $<0.001$ \\
\hline dOM $\%$ & 53.3 & 56.5 & 56.3 & 58.4 & 0.14 & $<0.001$ & $<0.001$ \\
\hline M EI ,M J/d/sheep & 8.8 & 10.3 & 10.9 & 11.3 & 0.17 & $<0.001$ & $<0.001$ \\
\hline LWG g/day & 68 & 84 & 62 & 81 & 2.53 & 0.41 & 0.01 \\
\hline
\end{tabular}

Conclusions The results based on these two years show ed that the grazing system affected quality of feed ,digestibility and intake in sheep grazing on the Inner Mongolian steppe ,but the LWG w as not affected. Further studies are required in years with mean precipitations before final evaluation of the grazing systems can be made .

\section{References}

Wang CJ (2007) Dissertation, University of Kiel .

McDonald P ,Edwards RA ,Greenhalgh JFD (1988) A nimal Nutrition. Copublished in United State with John Wiley and Sons, Inc . New York . pp . 245-259. 